\title{
Development of Myxobolus macrocapsularis (Myxosporea: Myxobolidae) in an oligochaete alternate host, Tubifex tubifex
}

\author{
Cs. Székely*, O. Rácz, K. Molnár, E. Eszterbauer \\ Veterinary Medical Research Institute, Hungarian Academy of Sciences, PO Box 18, 1581 Budapest, Hungary
}

\begin{abstract}
The development of Myxobolus macrocapsularis Reuss, 1906, a myxosporean parasite of the gills of common bream Abramis brama L., was studied in experimentally infected oligochaetes. In 3 experiments uninfected Tubifex tubifex Müller and Limnodrilus hoffmeisteri (Claparéde) were exposed to mature myxospores of $M$. macrocapsularis. In all experiments, typical triactinospores developed in T. tubifex specimens but no infection was found in $L$. hoffmeisteri. Triactinospores were released from oligochaetes 66 to $99 \mathrm{~d}$ after initial exposure. At that time pansporocysts containing 8 triactinospores were located in the gut epithelium of experimental oligochaetes, but free actinosporean stages were also found in the gut lumen of the oligochaetes. Each triactinospore had 3 pyriform polar capsules and a barrel-shaped sporoplasm with 32 secondary cells. The spore body joined the 3 caudal projections with a stout style.
\end{abstract}

KEY WORDS: Myxobolus macrocapsularis - Myxospore · Gill parasite • Abramis brama . Intraoligochaete development · Tubifex tubifex · Triactinospore

\section{INTRODUCTION}

Myxobolus macrocapsularis Reuss, 1906, described from the white bream Blicca bjoerkna as type host, seems to be one of the most commonly occurring myxosporeans on the gills of the common bream Abramis brama L. in Lake Balaton (Molnár \& Székely 1999). Some aspects of its location and intrapiscine development were studied also by the above authors. Nothing was known, however, about its extrapiscine developmental stages.

Since the intraoligochaete developmental phase of Myxobolus cerebralis Hofer was first described by Wolf \& Markiw (1984), several other authors have supported the theory that the development of other myxosporeans was also accomplished through oligochaete and fish alternate hosts. They (El-Matbouli \& Hoff-

*E-mail: szekely@vmri.hu mann 1989, 1993, Ruidisch et al. 1991, Styer et al. 1991, El-Matbouli et al. 1992, Grossheider \& Körting 1992, Benajiba \& Marquès 1993, Kent et al. 1993, Yokoyama et al. 1993, 1995, Uspenskaya 1995, Trouillier et al. 1996, Yokoyama 1997, El-Mansy \& Molnár 1997a,b, ElMansy et al. 1998, Székely et al. 1998, Molnár et al. 1999a,b, Székely et al. 1999, Eszterbauer et al. 2000) reported that in each case various oligochaetes proved to be alternate hosts in the development of various myxosporean species. Recent studies have suggested, however, that besides oligochaetes some polychaetes (Bartholomew et al. 1997, Køie 2000) and bryozoans (Longshaw et al. 1999, Kent et al. 2000) can also serve as alternate hosts for fish myxosporeans.

The work presented in this paper forms part of continuing experimental life cycle studies conducted on the most common myxosporeans of Hungarian fish species. In the experiments reported here, the intraoligochaete development of Myxobolus macrocapsularis was followed in Tubifex tubifex. 


\section{MATERIALS AND METHODS}

Spores of Myxobolus macrocapsularis (Fig. 1) were collected from mature plasmodia of the gills of 3- to 5 -yr-old common bream Abramis brama seined in Lake Balaton and in the Kis-Balaton Water Reservoir, Hungary. Plasmodia containing about 800000 to 1200000 spores were located at the tip of the gill filaments, which extended characteristically over the tip of the uninfected ones (Fig. 2). Plasmodia were removed mechanically from the gill filaments. For exposure of oligochaetes, myxospores released from plasmodia were identified under a coverslip with a compound microscope.

The method of collection and laboratory culture of oligochaetes free from actinosporean infection were the same as those described by Székely et al. (1999) and Eszterbauer et al. (2000). The oligochaete stock was composed of an about equal number of Tubifex tubifex and Limnodrilus hoffmeisteri cultured in our laboratory for 5 yr continuously.

Three experiments were performed. In Expt 1, 100 specimens of Tubifex tubifex and Limnodrilus hoff- meisteri were placed into a small plastic cup of $500 \mathrm{ml}$ volume. About 100000 spores of Myxobolus macrocapsularis were added at the same time so that the spore:worm ratio was 1000:1. In Expt 2 an undetermined number of spores from 3 mature $M$. macrocapsularis plasmodia was added to a plastic cup containing 100 specimens of T. tubifex and L. hoffmeisteri. In Expt 3, 100 oligochaete specimens ( $T$. tubifex and $L$. hoffmeisteri) were placed into a small plastic cup of $500 \mathrm{ml}$ volume. About 3 million M. macrocapsularis myxospores were added to oligochaetes. On Day 30 post infection an additional infection was made with 800000 myxospores. T. tubifex and L. hoffmeisteri specimens of the original stocks served as controls for the experiments.

All dishes (containing mud in their bottom) were permanently aerated and regularly supplied with fresh water to prevent evaporation and to refresh the water for the oligochaetes. Oligochaetes were fed granulated fish food weekly.

Starting from Day 30 post infection, water from the dishes was filtered through a fine mesh of $10 \mu \mathrm{m}$ pore size every week. The filtrates were taken up in a drop
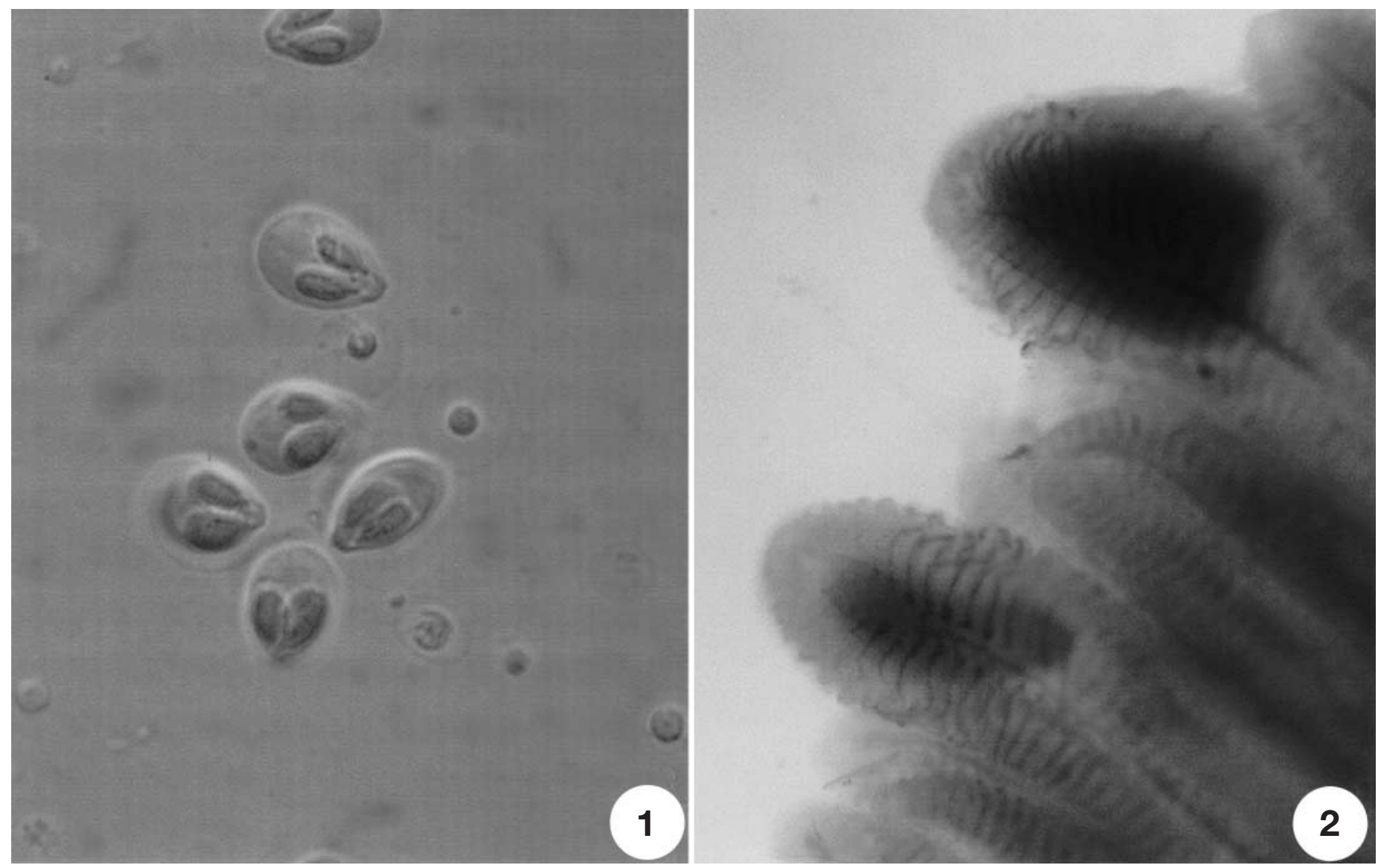

Figs. 1 \& 2. Myxobolus macrocapsularis. Fig. 1. M. macrocapsularis myxospores. Fresh preparation. $\times 1000$. Fig. 2. Typical location of M. macrocapsularis plasmodia in the afferent artery at the tip of the gill filaments. Fresh preparation. $\times 20$ 
of water and examined for the presence of actinospores. In the first experiment, we only studied released actinospores filtered from the water of the cup. In Expts 2 and 3, after the first release of triactinospores, all oligochaetes were placed into $2 \mathrm{ml}$ tissue culture plates according to Yokoyama et al. (1991), and after $1 \mathrm{~d}$ of incubation they were examined for the release of actinospores under a stereomicroscope. Triactinospores released by the oligochaetes were examined under a coverslip by compound microscope. They were recorded on videotapes and pictures were digitalised by the IMAGO $^{\circledR}$ program as described by Székely (1997). Photographs were taken with an Olympus DP-10 digital camera and drawings were made. Measurements of 52 triactinospores from the 3 experiments were recorded. In the description, all measurements are given in micrometres. The actinosporean stage of Myxobolus macrocapsularis was described using the terminology of Janiszewska (1957) as modified by Lom et al. (1997). The intensity of infection of worms releasing actinospores was checked in live conditions under a light microscope and specimens bearing high numbers of actinospores were fixed for histological and semithin sections.

The infected Tubifex tubifex specimens were fixed in Bouin's solution, embedded in Paraplast ${ }^{\circledR}$ (Monoject Sci) wax, cut into 4 to $8 \mu \mathrm{m}$ thick sections, and stained with haematoxylin and eosin. For the semithin section technique, infected T. tubifex specimens were fixed in $5 \%$ glutaraldehyde in cacodylate buffer for $1.5 \mathrm{~h}$, postfixed in $2 \%$ osmium tetroxide for $2 \mathrm{~h}$, washed several times with cacodylate buffer, dehydrated and embedded in Durcupan ACM resin. Semithin sections ( 0.5 to $1 \mu \mathrm{m}$ ) were stained with $0.1 \%$ toluidine blue solution.

\section{RESULTS}

\section{Light microscopy}

Actinospores of Myxobolus macrocapsularis were released only from experimentally infected Tubifex tubifex specimens. No infection was found in Limnodrilus hoffmeisteri, nor in the control T. tubifex specimens. In Expts 1, 2 and 3, actinospores floating in the water of the cups and showing a typical triactinomyxon morphology (Fig. 3) were first filtered on Days 69, 85 and 66, respectively, after initial exposure to M. macrocapsularis myxospores. In Expt 1, actinospores were seen only in the filtered water of the cup. In Expts 2 and 3, however, the release of actinospores was taking place continuously from individually controlled oligochaete specimens placed in cell-well plates. When oligochaetes in Expt 2 were placed in cell-well plates,
58 of the surviving specimens proved to be $T$. tubifex and 33 were identified as $L$. hoffmeisteri. Actinospores in plates were released only from $6 \mathrm{~T}$. tubifex specimens $(10 \%)$. No release of actinospores from $L$. hoffmeisteri was observed. In Expt 3, when the exposure of 61 T. tubifex and 27 L. hoffmeisteri to M. macrocapsularis spores was studied in cell-well plates, 7 specimens of T. tubifex $(11 \%)$ released actinospores. In the latter plates a new release of triactinospores was observed $98 \mathrm{~d}$ after the first introduction and $68 \mathrm{~d}$ after the second supplementation with myxospores. At that time 15 specimens $(18 \%)$ of the remaining $T$. tubifex started to release actinospores. No release of spores was observed from $L$. hoffmeisteri in this experiment either. In each experiment typical triactinomyxon-type actinospores were obtained. The release of triactinospores lasted about $26 \mathrm{~d}$ in Expt 1, $14 \mathrm{~d}$ in Expt 2, and 9 and $16 \mathrm{~d}$ in Expt 3. In heavily infected live T. tubifex specimens placed under a coverslip, pansporocysts were seen in the gut epithelium and free spores were observed in the lumen of the worm's intestine by means of a compound microscope (Fig. 4). From crushed T. tubifex specimens pansporocysts were obtained, each of which contained 8 developing triactinospores.

\section{Description of triactinospores}

Triactinospores (on the basis of 52 actinospores) (Table 1, Fig. 5) released from the worms' bodies and floating in the water were characterised by 3 pyriform polar capsules, a sporoplasm, a stout style and 3 relatively short caudal processes. Polar capsules were pyriform, $5.14 \mu \mathrm{m}$ (range 4 to $6 \mu \mathrm{m}$ ) in length and $3.8 \mu \mathrm{m}(3$ to $4 \mu \mathrm{m}$ ) in width (Fig. 6a). Sporoplasm was barrel shaped, $20.6 \mu \mathrm{m}$ (16 to $24 \mu \mathrm{m})$ long and $12 \mu \mathrm{m}$ (10 to $14 \mu \mathrm{m}$ ) wide, and contained 32 spherical secondary cells (Fig. 6b). The style was moderately long $(60.2 \mu \mathrm{m}$, range 53 to $69 \mu \mathrm{m})$. Its width, which was equal in its

Table 1. Measurements of the live triactinospores of Myxobolus macrocapsularis $(\mathrm{n}=52$ actinospores)

\begin{tabular}{|llcrr|}
\hline \multirow{2}{*}{ Dimension $(\mu \mathrm{m})$} & & Mean $\pm \mathrm{SD}$ & Min. & Max. \\
\hline Polar capsules & Length & $5.14 \pm 0.59$ & 4 & 6 \\
& Width & $3.8 \pm 0.2$ & 3 & 4 \\
Sporoplasm & Length & $20.57 \pm 1.5$ & 16 & 24 \\
& Width & $12 \pm 0.86$ & 10 & 14 \\
Spore body & Length & $27.15 \pm 1.895$ & 23 & 31 \\
& Width & $12 \pm 0.86$ & 10 & 14 \\
Style & Length & $60.15 \pm 3.27$ & 53 & 69 \\
Caudal & Width & $9.47 \pm 0.5$ & 9 & 10 \\
processes & Length & $116.61 \pm 11.17$ & 94 & 141 \\
& Width & $8.5 \pm 0.623$ & 8 & 10 \\
\hline
\end{tabular}



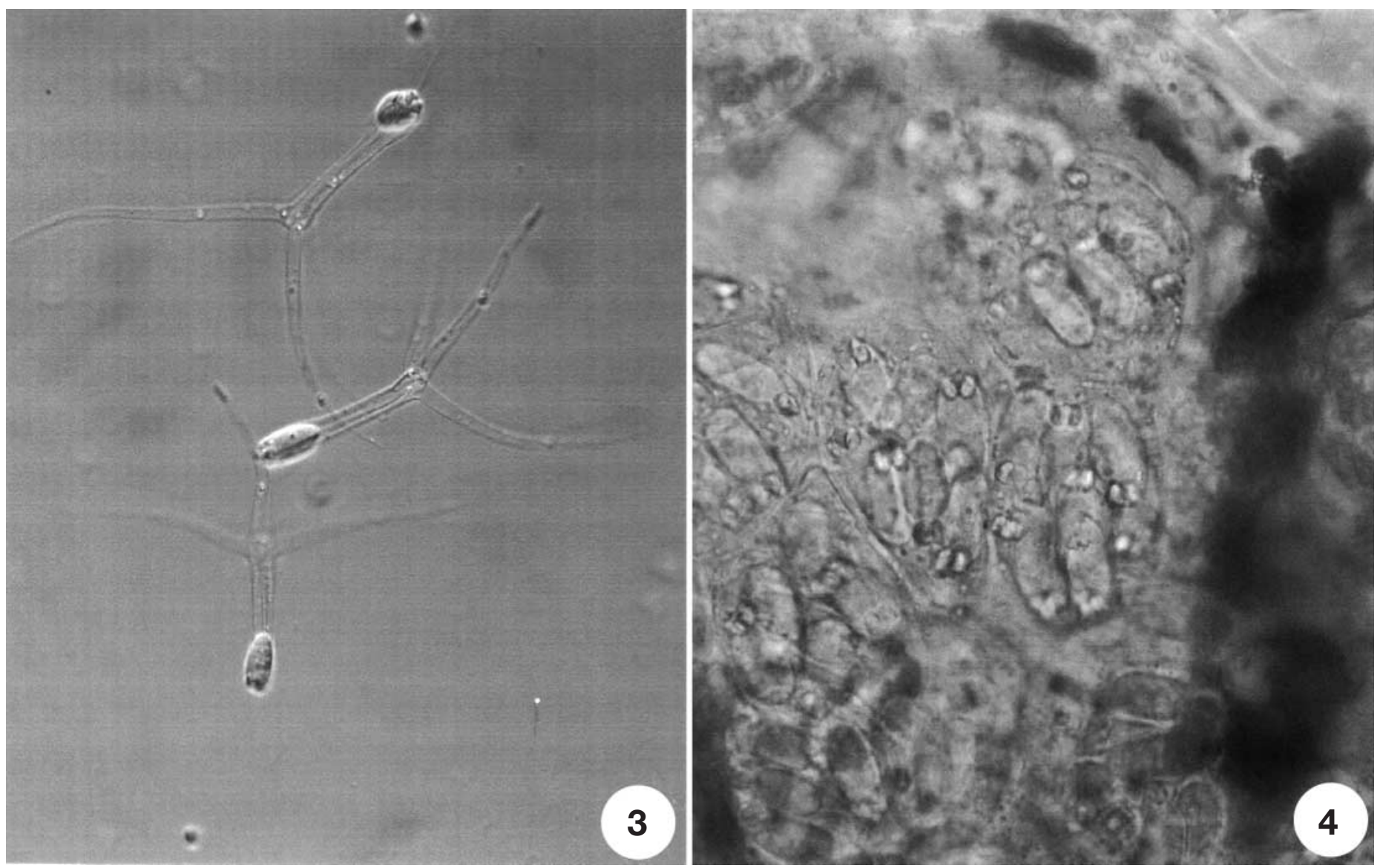

Figs. 3 \& 4. Fig. 3. Floating triactinospores of Myxobolus macrocapsularis released from Tubifex tubifex. Fresh preparation. $\times 350$. Fig. 4 . Squash preparation of a $T$. tubifex infected with pansporocysts of $M$. macrocapsularis. Each pansporocyst contains 8 triactinospores. Fresh preparation. $\times 500$

whole length, measured $9.5 \mu \mathrm{m}$ (9 to $10 \mu \mathrm{m})$. Caudal processes were slightly bent or straight, tapering towards the end and terminating in a sharp point. The length of the caudal processes was $116.6 \mu \mathrm{m}(94$ to $141 \mu \mathrm{m})$, and their width at the origin was $8.5 \mu \mathrm{m}$ (8 to $10 \mu \mathrm{m})$. The length from the apical point of polar capsules to the end of sporoplasm (spore body) measured $20.6 \mu \mathrm{m}$ (16 to $24 \mu \mathrm{m}$ ).

Fig. 5. Schematic drawing of the triactinospore of Myxobolus macrocapsularis. Scale bar $=45 \mu \mathrm{m}$ 


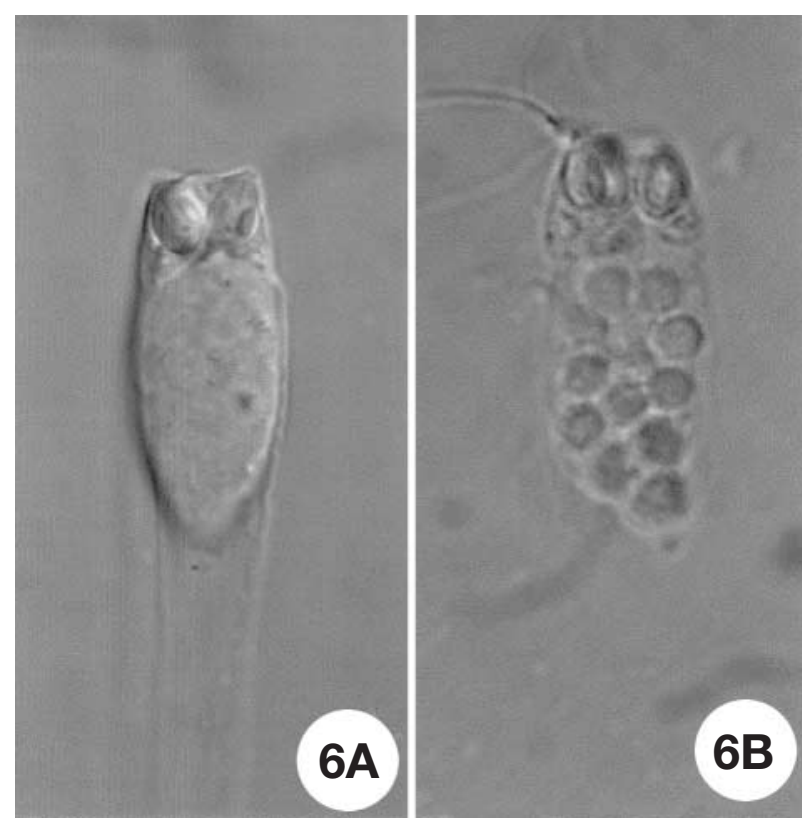

Fig. 6. Spore body of Myxobolus macrocapsularis triactinospores. (A) In the uncompressed triactinospore a barrelshaped sporoplasm with less contrasted secondary cells and 2 of the 3 polar capsules at the tip are seen. (B) In a more compressed triactinospore polar capsules with released polar filaments and some of the 32 secondary cells are seen. Fresh preparation. $\times 1500$

\section{Differential diagnosis}

The triactinospore of Myxobolus macrocapsularis differs from most of the known species by its small size and its barrel-shaped sporoplasm. The total length of the spore body and the style is much shorter than that of $M$. arcticus, $M$. bramae, $M$. cerebralis, $M$. hungaricus, M. portucalensis and $M$. pseudodispar. In their small size, triactinospores of $M$. macrocapsularis resemble those of $M$. cotti but their barrel-shaped sporoplasm differs significantly from the elongated sporoplasm of the latter species.

\section{Histology}

In histological sections and in semithin sections fixed in the period of actinospore release, heavy infection with mature pansporocysts was found in the gut epithelium of the worms. At that time most of the segments of the worms were infected with round or elliptical pansporocysts, each harbouring 8 triactinospores (Fig. 7). In one of the specimens fixed from Expt 3 both early developmental stages and pansporocysts with fully matured spores were found. In pansporocysts located intracellularly in epithelial cells, the polar cap- sules, the secondary cells of the sporoplasm and the folded caudal processes of the triactinospores were easily distinguishable (Fig. 8). Pansporocysts were segregated from the lumen of the worm's intestine by only a thin layer of the ectoplasm of the infected epithelial cells.

\section{DISCUSSION}

Myxobolus macrocapsularis is a relatively little studied parasite of the common bream. In spite of its common occurrence, little is known about its pathogenicity although the intrapiscine development and site preference on the gills were studied by Molnár \& Székely (1999). Data obtained in this study show for the first time that the intraoligochaete development of this parasite follows the same pattern as that described by Wolf \& Markiw (1984) for M. cerebralis. In our experiments the development of $M$. macrocapsularis was successfully completed in Tubifex tubifex, in which typical triactinomyxon-type spores developed. From the experiments, it can be concluded that, of the 2 oligochaete species used, only T. tubifex is a suitable alternate host for $M$. macrocapsularis, since no development took place in Limnodrilus hoffmeisteri.

The prevalence of infection varied in experiments and no measurable correlation between the infection rate of oligochaetes and the number of myxospores introduced into the cups could be determined. The prevalence of infection did not reach the level obtained earlier in this laboratory with Myxobolus drjagini, $M$. portucalensis, M. hungaricus and $M$. dispar (El-Mansy \& Molnár 1997a,b, El-Mansy et al. 1998, Molnár et al. 1999a), but on a lower level M. macrocapsularis infected the oligochaetes consistently in all the experiments.

As all 3 experiments were done within a relatively narrow temperature range (room temperature), only scarce information was obtained on the temperature that is optimal for the development of the species. Nevertheless, from the data obtained we could conclude that the period of prepatent development was relatively short compared with that of other myxosporean species, and actinospores were formed in less than 3 mo. A certain synchronism was found in actinospore release, as in the majority of cases triactinospores were released within 2 wk. Expt 3 also showed that reinfection of the already challenged oligochaete stock with further myxospores was successful, and in 1 Tubifex tubifex specimen there was evidence of the presence of 2 different actinospore generations, indicating a possible reinfection of an already infected specimen. 


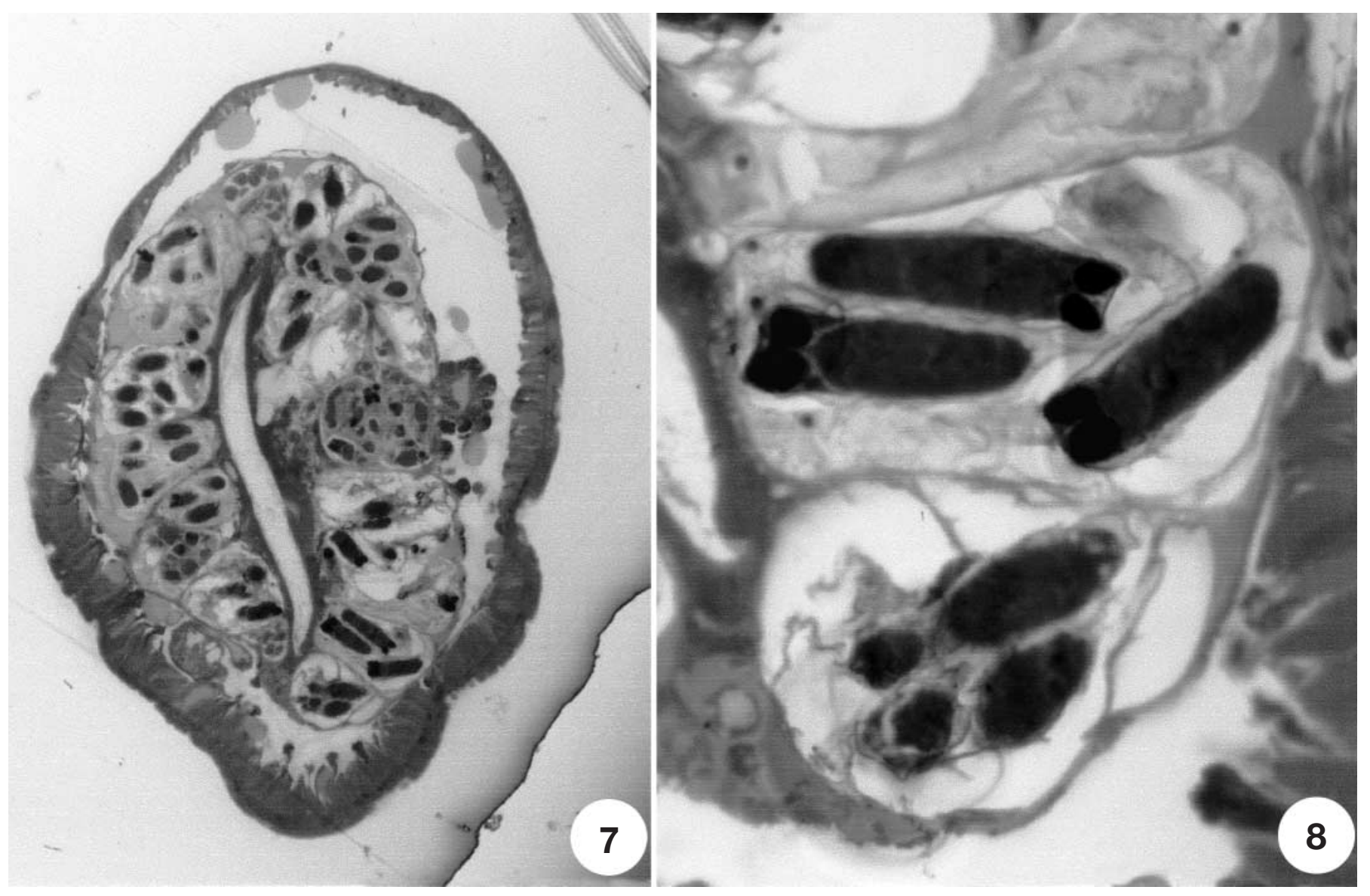

Figs. 7 \& 8. Fig. 7. Cross-section of an infected Tubifex tubifex fixed $69 \mathrm{~d}$ after initial exposure to Myxobolus macrocapsularis spores. Pansporocysts of $M$. macrocapsularis are located in the epithelial cells of the intestine. Each pansporocyst contains 8 well-developed triactinospores. The pansporocyst is segregated from the lumen of the gut only by a thin layer of the ectoplasm. Semithin section. $\times 300$. Fig. 8. Cross-section of the gut of an infected T. tubifex fixed $69 \mathrm{~d}$ after initial exposure. In 2 pansporocysts mature triactinospores with dark-staining polar capsules and sporoplasms are seen. The space of the pansporocyst is filled by the folded caudal processes of the spores. Semithin section. $\times 1500$

Histological data suggest that early development of the species takes place in the intestinal epithelium of Tubifex tubifex from where mature pansporocysts are released into the intestinal lumen. The intact body wall of oligochaetes infers that actinospores reach the water through the anal opening of the worm.

Acknowledgements. The study was supported by the Hungarian Scientific Research Fund (OTKA, contracts no. T31755 and T29200). The authors thank Ms Zsuzsa Kis for making the semithin sections. The authors are grateful to Dr. András Specziár and István Báthory, Limnological Research Institute, HAS and the Balaton Fisheries Co. for collecting common bream.

\section{LITERATURE CITED}

Bartholomew JL, Whipple MJ, Stevens DG, Fryer JL (1997) The life cycle of Ceratomyxa shasta a myxosporean para- site of salmonids requires a freshwater polychaete as an alternate host. J Parasitol 83:859-868

Benajiba MH, Marquès A (1993) The alternation of actinomyxidian and myxosporidian sporal forms in the development of Myxidium giardi (parasite of Anguilla anguilla) through oligochaetes. Bull Eur Assoc Fish Pathol 13:100-103

El-Mansy A, Molnár K (1997a) Extrapiscine development of Myxobolus drjagini Akhmerov, 1954 (Myxosporea, Myxobolidae) in oligochaete alternative hosts. Acta Vet Hung 45:427-438

El-Mansy A, Molnár K (1997b) Development of Myxobolus hungaricus (Myxosporea: Myxobolidae) in oligochaete alternate hosts. Dis Aquat Org 31:227-232

El-Mansy A, Molnár K, Székely Cs (1998) Development of Myxobolus portucalensis Saraiva \& Molnár, 1990 (Myxosporea: Myxobolidae) in the oligochaete Tubifex tubifex (Müller). Syst Parasitol 41:95-103

El-Matbouli M, Hoffmann RW (1989) Experimental transmission of two Myxobolus spp. developing by sporogeny via tubificid worms. Parasitol Res 75:461-464

El-Matbouli M, Hoffmann RW (1993) Myxobolus carassii Klokacheva, 1914 also requires an aquatic oligochaete, Tubifex 
tubifex as intermediate host in its life cycle. Bull Eur Assoc Fish Pathol 13:189-192

El-Matbouli M, Fischer-Scherl T, Hoffmann RW (1992) Transmission of Hoferellus carassii Achmerov, 1960 to goldfish Carassius auratus via an aquatic oligochaete. Bull Eur Assoc Fish Pathol 12:54-56

Eszterbauer E, Székely Cs, Molnár K, Baska F (2000) Development of Myxobolus bramae (Myxosporea: Myxobolidae) in an oligochaete alternate host, Tubifex tubifex. J Fish Dis 23:19-25

Grossheider G, Körting W (1992) First evidence that Hoferellus cyprini (Doflein, 1898) is transmitted by Nais sp. Bull Eur Assoc Fish Pathol 12:17-20

Janiszewska J (1957) Actinomyxidia II. New systematics, sexual cycles, description of new genera and species. Zool Pol 8:3-34

Kent ML, Whitaker DJ, Margolis L (1993) Transmission of Myxobolus arcticus Pugachev and Khokhlov, 1979, a myxosporean parasite of Pacific salmon, via a triactinomyxon from the aquatic oligochaete Stylodrilus heringianus (Lumbriculidae). Can J Zool 71:1207-1211

Kent ML, Khattra J, Hedrick RP, Devlin RH (2000) Tetracapsula renicola n. sp. (Myxozoa: Saccosporidae); the PKX myxozoan: the cause of proliferative kidney disease of salmonid fishes. J Parasitol 86:103-111

Køie M (2000) First record of an actinosporean (Myxozoa) in a marine polichaete Annelid. J Parasitol. 86:871-872

Lom J, McGeorge J, Feist SW, Morris D, Adams A (1997) Guidelines for the uniform characterisation of the actinosporean stages of parasites of the phylum Myxozoa. Dis Aquat Org 30:1-9

Longshaw M, Feist SW, Canning EU, Okamura B (1999) First identification of PKX in bryozoans from the United Kingdom: molecular evidence. Bull Eur Assoc Fish Pathol 19: 146-148

Molnár K, Székely Cs (1999) Survey on Myxobolus infection of the gills of the common bream (Abramis brama L.) in Lake Balaton and Kis-Balaton reservoirs. Acta Vet Hung 47:419-432

Molnár K, El-Mansy A, Székely Cs, Baska F (1999a) Development of Myxobolus dispar Thelohan, 1895 (Myxosporea: Myxobolidae) in an oligochaete alternate host Tubifex tubifex (Müller). Folia Parasitol 46:15-21

Molnár K, El-Mansy A, Székely Cs, Baska F (1999b) Development of Sphaerospora renicola Dykova and Lom, 1982 (Myxosporea: Sphaerosporidae) in oligochaete alternate hosts. J Fish Dis 22:1-11

Ruidisch S, El-Matbouli M, Hoffmann RW (1991) The role of tubificid worms as an intermediate host in the life cycle of

Editorial responsibility: Wolfgang Körting,

Hannover, Germany
Myxobolus pavlovskii (Akhmerov, 1954). Parasitol Res 77:663-667

Styer EL, Harrison LR, Burtle GJ (1991) Experimental production of proliferative gill disease in channel catfish exposed to a myxozoan-infected oligochaete, Dero digitata. J Aquat Anim Health 3:288-291

Székely Cs (1997) Possible applications of video technology and digital image processing in fish parasitology: morphological examination of the groups Apicomplexa and Myxosporea-Actinosporea by video-technology. Bull Eur Assoc Fish Pathol 17:81-82

Székely Cs, El-Mansy A, Molnár K, Baska F (1998) Development of Thelohanellus hovorkai and Thelohanellus nikolskii (Myxosporea: Myxozoa) in oligochaete alternate hosts. Fish Pathol 33:107-114

Székely Cs, Molnár K, Eszterbauer E, Baska F (1999) Experimental detection of the actinospores of Myxobolus pseudodispar (Myxosporea: Myxobolidae) in oligochaete alternate hosts. Dis Aquat Org 38:219-224

Trouillier A, El-Matbouli M, Hoffmann RW (1996) A new look at the life-cycle of Hoferellus carassii in the goldfish (Carassius auratus auratus) and its relation to 'kidney enlargement disease' (KED). Folia Parasitol 43:173-187

Uspenskaya AV (1995) Alternation of actinosporean and myxosporean phases in the life cycle of Zschokella nova (Myxozoa). J Eukaryot Microbiol 42:665-668

Wolf K, Markiw ME (1984) Biology contravenes taxonomy in the myxozoa: new discoveries show alternation of invertebrate and vertebrate hosts. Science 225:1449-1452

Yokoyama H (1997) Transmission of Thelohanellus hovorkai Achmerov, 1960 (Myxosporea: Myxozoa) to common carp Cyprinus carpio through the alternate oligochaete host. Syst Parasitol 36:79-84

Yokoyama H, Ogawa K, Wakabayashi H (1991) A new collection method of actinosporeans. A probable infective stage of myxosporeans to fishes from tubificids and experimental infection of goldfish with the actinosporean, Raabeia sp. Fish Pathol 26:133-138

Yokoyama H, Ogawa K, Wakabayashi H (1993) Involvement of Branchiura sowerbyi (Oligochaeta: Annelida) in the transmission of Hoferellus carassii (Myxosporea: Myxozoa), the causative agent of kidney enlargement disease (KED) of goldfish Carassius auratus. Fish Pathol 28: 135-139

Yokoyama H, Ogawa K, Wakabayashi H (1995) Myxobolus cultus n. sp. (Myxosporea: Myxobolidae) in the goldfish Carassius auratus transformed from the actinosporean stage in the oligochaete Branchiura sowerbyi. J Parasitol 81:446-451

Submitted: April 15, 2001; Accepted: September 10, 2001 Proofs received from author(s): March 5, 2002 